\title{
Estimation of maximum thermo-hygrometric index thresholds affecting milk production in Italian Brown Swiss cattle
}

\author{
A. Maggiolino, ${ }^{1 *} \odot$ G. E. Dahl, ${ }^{2} \odot$ N. Bartolomeo, ${ }^{3} \odot$ U. Bernabucci, ${ }^{4} \odot$ A. Vitali, ${ }^{4} \odot$ G. Serio, ${ }^{3} \odot$ M. Cassandro,,${ }^{5} \odot$ \\ G. Centoducati, ${ }^{1}$ E. Santus, ${ }^{6}$ and P. De Palo ${ }^{1}$ (i) \\ ${ }^{1}$ Department of Veterinary Medicine, University of Bari A. Moro, 70010 Valenzano, Italy \\ ${ }^{2}$ Department of Animal Sciences, University of Florida, Gainesville 32611 \\ ${ }^{3}$ Medical Statistics, Department of Biomedical Science and Human Oncology, University of Bari, 70124 Bari, Italy \\ ${ }^{4}$ Department of Agriculture and Forest Sciences (DAFNE), University of Tuscia, Viterbo 01100, Italy \\ ${ }_{6}^{5}$ Department of Agronomy, Food, Natural resources, Animals and Environment, University of Padova, Agripolis, Legnaro (Padova), 35020, Italy \\ ${ }^{6}$ Italian Brown Breeders Association, Loc. Ferlina 204, Bussolengo 37012, Italy
}

\section{ABSTRACT}

It is known that heat stress affects dairy cow performance in multiple ways: physiological, behavioral, reproductive, and productive. The aim of the present study was to determine if a threshold of temperaturehumidity index (THI) exists for multiple milk production traits (milk yield, fat-corrected milk, protein and fat yield and percentage, energy-corrected milk, cheese production, and cheese yield) in Italian Brown Swiss dairy cows from the period $15 \mathrm{~d}$ before the day of the Italian Breeders Association test-day sampling. A 10yr data set (2009-2018) containing 202,776 test-day records of 23,296 Brown Swiss cows was matched with the maximum THI. In all parities considered, no THI thresholds were observed for milk yield in Brown Swiss. In contrast, a THI threshold of 75 was identified for fat-corrected milk. No THI threshold was found for fat percentage, but fat yield showed the highest THI thresholds in cows of first and second parity. Protein yield and cheese production were affected by heat stress with average THI threshold of 74 . The THI thresholds identified indicate that the Brown Swiss breed has higher thermal tolerance versus literature values reported for Holstein cows. As THI rises, Brown Swiss cows tend to produce the same volume of milk, but with a decreasing quality with regard to components. Further study is necessary to estimate the genetic component of heat tolerance, in Brown Swiss cattle, considering that the correct estimation of THI thresholds represents the first step to identify components that could be included in selection procedures.

Key words: Brown Swiss, temperature-humidity index threshold, heat stress, milk quality

Received March 31, 2020.

Accepted May 6, 2020.

*Corresponding author: aristide.maggiolino@uniba.it

\section{INTRODUCTION}

Climatic conditions are expected to affect the welfare and productive performance of livestock (Hill and Wall, 2015; Nasr and El-Tarabany, 2017; Amamou et al., 2019; Cassandro, 2020), and heat stress is one of the major factors that negatively influences milk yield of lactating cows, particularly in animals of high genetic merit (Kadzere et al., 2002; Nardone et al., 2010). In fact, lactating cows are most sensitive to thermal stress, due to the metabolic heat load produced from nutrient digestion and milk synthesis, which is proportional to milk yield (Nasr and El-Tarabany, 2017). The relationship between high milk yield and heat tolerance has been studied in Holstein cows by several authors (Aguilar et al., 2010; Bernabucci et al., 2014; Beux et al., 2017; Amamou et al., 2019) and it is well demonstrated that the level of milk yield negatively affects thermal tolerance (Ravagnolo and Misztal, 2002; Wheelock et al., 2010; Bernabucci et al., 2014), but few studies have been conducted in Brown Swiss cows, perhaps due to the perceived higher heat tolerance versus Holstein cows, although those studies were conducted measuring the increase of rectal temperature under heat stress, and not observing productive traits (Correa-Calderon et al., 2004). The effect of heat stress on dairy cows is of growing interest as an attempt to anticipate problems related to global warming (Dikmen and Hansen, 2009). Several bioclimatic indices can be considered as predictors of heat stress, based on different weather variables such as dry bulb temperature, relative humidity, solar radiation, and wind speed (Dikmen and Hansen, 2009). However, temperature-humidity index (THI), which is a combination of dry bulb temperature and relative humidity, is the most widespread indicator of heat stress used in dairy cows (Hammami et al., 2013; Heinicke et al., 2018). Different methods have been applied to describe environmental conditions using THI, such as 
average THI per hour, average per day, or average per daytime or nighttime part of the day (Cincović et al., 2011; Herbut and Angrecka, 2018). Some studies report that maximum daily THI values were more highly correlated with productive traits relative to other THI indices (Ravagnolo and Misztal, 2002; Bernabucci et al., 2014; Beux et al., 2017). Temperature-humidity index thresholds or classes were suitable for estimating the intensity of thermal discomfort (Endres and Barberg, 2007; Allen et al., 2015), and defining a THI of 72 is the threshold in Holstein cows for the initial limit for heat stress and consequently the first decrease in milk production (Heinicke et al., 2018). However, it has been shown that a THI in the range of 62 to 69 can reduce milk yield (Zimbelman et al., 2009; Bernabucci et al., 2014; Lambertz et al., 2014). Most of the existing studies examining the effects of heat stress on behavioral (De Palo et al., 2006; Uzal Seyfi, 2013; Allen et al., 2015; Herbut and Angrecka, 2018; Heinicke et al., 2018, 2019), physiological (Dikmen and Hansen, 2009; Amamou et al., 2019; Jeelani et al., 2019), productive (Hammami et al., 2013; Bohlouli et al., 2013; Bernabucci et al., 2014), and milk processing characteristics (Beux et al., 2017) were carried out on Holstein cows, probably because it is the predominant breed of dairy animal globally, whereas less is known about breed differences in thermal tolerance. To date, no studies are available dealing with heat stress effects and THI thresholds in Brown Swiss dairy cows. Although Brown Swiss cows are less numerous worldwide than Holsteins, they are used heavily for cheese production because of the milk component profile. Therefore, the aim of this study was to identify in Brown Swiss dairy cows, for each productive parameter, including milk yield, FCM yield, protein and fat yield and protein and fat percentage, cheese yield and cheese production, the THI threshold points and time period across parities, if present, when productive variables (milk yield, constituents, or both) start to decline.

\section{MATERIALS AND METHODS}

\section{Data Set Management}

Data were provided by the Italian Brown Swiss Breeders Association (Verona, Italy) and comprised $1,048,570$ test-day records of 85,379 Brown Swiss cows. Records were collected from 749 Italian farms and dated from 2009 through 2018. The first editing of the raw data set followed the listed exclusion criteria: all farms located over $700 \mathrm{~m}$ above sea level; all farms with less than 10 lactating cows; all cows that did not have at least 5 test-day records per lactation; all cows were required to have first lactation data; all cows that did not have at least 15 test-day records per farm among all lactations; all test-day records over 365 DIM; and testday records lacking at least one of the following traits: milk yield, protein percentage, fat percentage, or SCC.

After initial editing, the data set consisted of 957,449 test-day records for 76,946 cows on 698 farms. All data were recorded and collected according to the International Committee for Animal Recording Standards guidelines in force from 2009 to 2018 (ICAR, 2019). Daily production traits considered were milk yield (MY), and protein and fat percentages. From these data, yields of protein and fat were calculated and expressed as kilograms per day. Moreover, FCM yield, standardized at $4 \%$ fat, was calculated for each test-day record according to the following formula (Gaines and Davidson, 1923):

$$
4 \% \mathrm{FCM}=0.4 \times \text { milk }+15 \times \text { fat } .
$$

Cheese yield as \% [1] was calculated on the basis of the formula reported by Van Slyke and Publow (1910) and cheese production at $24 \mathrm{~h}$ [2] was calculated on the basis of the formula reported by Formaggioni et al. (2015), both for each test-day record as follows:

$$
\begin{aligned}
\text { cheese yield }= & \{[0.93 \times \% \text { fat }+(\% \text { casein }-0.10)] \\
& \times 1.09\} /(100-\mathrm{M}),
\end{aligned}
$$

where fat recovery factor is 0.93 ; factor accounting for casein loss is $0.1 ; 1.09$ represents the constituents of cheese solids noncasein and nonfat, corresponding to $9 \%$ of the sum; $\mathrm{M}$ is the moisture of fresh cheese, assumed as $39.5 \%$ (as for 24-h Parmigiano-Reggiano cheese; Formaggioni et al., 2015).

$$
\text { Cheese production at } 24 \mathrm{~h}=\mathrm{SY} \times \mathrm{MY} 24 \mathrm{~h} \text {, }
$$

where MY24h is milk yield ( $\mathrm{kg}$ in $24 \mathrm{~h}$ ) and SY is the standard yield and is calculated as follows:

$$
\begin{gathered}
\mathrm{SY}=[(\mathrm{MY} 24 \mathrm{~h}-0.0944004) / 0.0104959] \\
\quad \times 0.0064+0.0862 ; \\
\mathrm{MY} 24 \mathrm{~h}=\{[0.84 \times \% \text { fat }+(\% \text { casein } \times 0.944)] \\
\quad \times 1.09\} /(100-39.5) .
\end{gathered}
$$

Obtained by adapting the Van Slyke and Publow (1910) formula to 24-h Parmigiano-Reggiano cheese characteristics, 0.84 is the fat recovery factor, 0.944 is the theoretical casein factor recovery. 
Climatic data were recorded from 76 weather stations, recognized by the World Meteorological Organization (WMO, 2019) and provided by the Italian Airforce (26 stations) and a private company (50 stations, Meteonetwork, Milan, Italy). The weather stations were selected because they recorded data in the decade considered (2009-2018) for at least 3,400 cumulative days. The environmental temperatures and relative humidity were recorded every hour. This data set was used for calculating hourly THI according to the formula used by Bernabucci et al. (2014):

$$
\begin{aligned}
\mathrm{THI}= & (1.8 \times \mathrm{AT}+32)-(0.55-0.55 \times \mathrm{RH}) \\
& \times[(1.8 \times \mathrm{AT}+32)-58],
\end{aligned}
$$

where AT is the environmental temperature expressed in degrees Celsius, so that the term $(1.8 \times \mathrm{AT}+$ 32 ) represents the conversion of temperature data in degrees Fahrenheit, and $\mathrm{RH}$ is the relative humidity as a fraction of unit. For each day the maximum and minimum daily THI values were selected, whereas the daily average THI value was calculated through the arithmetic mean between the hourly THI values during the day.

Farms and weather stations were geo-localized and several distances between each farm and each station were calculated. Subsequently, each farm was associated with the nearest weather station (no more than $10 \mathrm{~km}$ away) and weather and production data were merged. Each test-day record was associated with daily THI (maximum, minimum, and mean THI) recorded the day of the test and with daily THI values up to 15 $\mathrm{d}$ before the test.

At this stage, a secondary edit of the data was made, and the following criteria were adopted: farms that had no weather stations within $10 \mathrm{~km}$; farms linked to a weather station at a different altitude $(>50 \mathrm{~m})$; and farms that had significant orography or hydrographic bodies separating them from the weather station. The final data set used for the statistical analysis had the characteristics listed in Table 1 and derived from farms and weather stations distributed around all of Italy as illustrated in Figure 1.

Table 1. Characteristics of the final data set of the Brown Swiss cow population involved in the present analysis

\begin{tabular}{ll}
\hline Item & \\
\hline Study period & Jan. 1, 2009, to Dec. 31, 2018 \\
Geographic area & Italy \\
Number of farms & 639 \\
Number of cows & 23,296 \\
Number of weather stations & 73 \\
Number of total test-day records & 202,776 \\
\hline
\end{tabular}

Journal of Dairy Science Vol. 103 No. 9, 2020

\section{Statistical Analysis}

Two sets of analyses were carried out as reported by Bernabucci et al. (2014) in Holstein cows. First, a mixed linear model with repeated measures was fitted to obtain least squares estimates of THI effect on production traits:

$$
\begin{gathered}
Y=\operatorname{farm}(y c)+m c(y c)+c d i m+\text { Thir }+ \text { ord } \\
+ \text { thir } \times \text { ord }+ \text { cdim } \times \text { ord }+u+e,
\end{gathered}
$$

where $Y$ is the outcome (MY, FCM, $\mathrm{kg} / \mathrm{d})$, fat (\%), fat yield $(\mathrm{kg} / \mathrm{d})$, protein $(\%)$, protein yield $(\mathrm{kg} / \mathrm{d})$, cheese yield, equivalent cheese milk and cheese milk production in $24 \mathrm{~h} ; \operatorname{farm}(y c)$ is the fixed effect of the herd nested within the year of calving $(y c) ; m c(y c)$ is the fixed effect of the month of calving $(m c)$ nested within the year of calving; cdim is the fixed effect of DIM class; Thir is the fixed effect of THI maximum class; ord is the fixed effect of parity class; thir $\times$ ord is the fixed effect of the THI class by parity class; cdim $\times$ ord is the fixed effect of the DIM class by parity class; $u$ is the random factor that corrects for repeated measures of cows, and $e$ is the random residual effect.

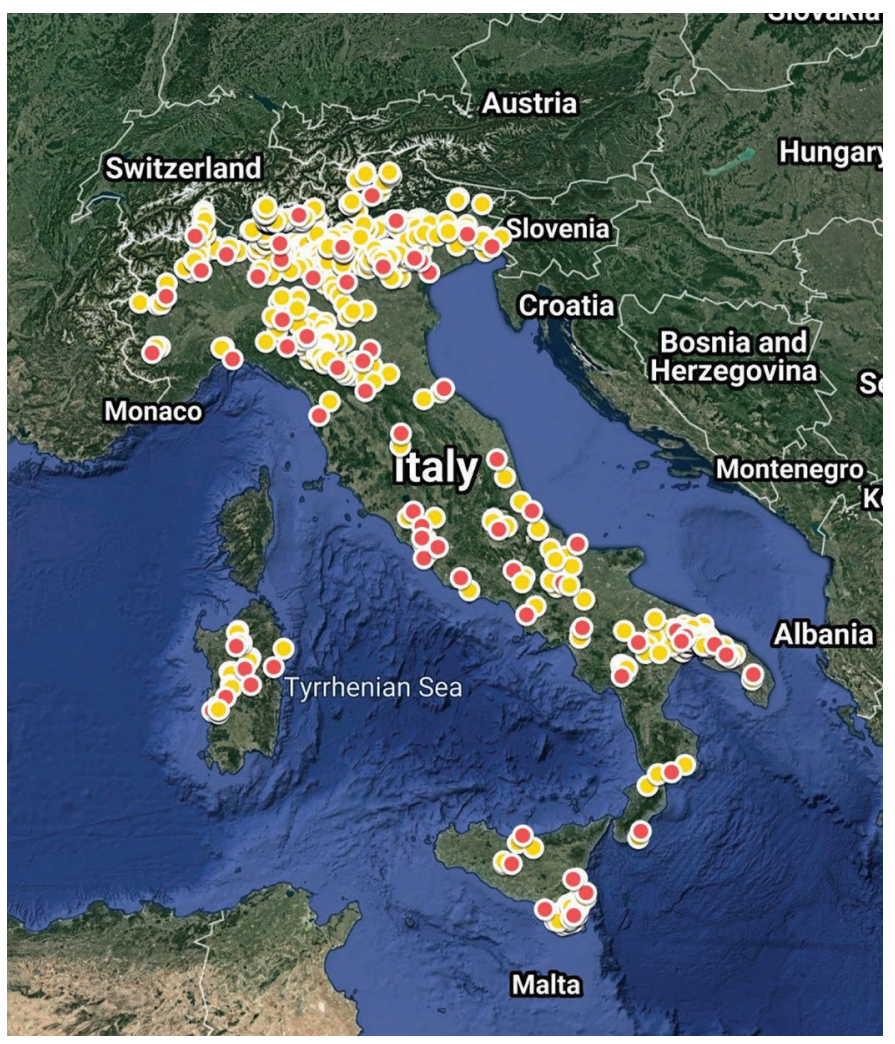

Figure 1. Map of the distribution of farms (yellow dots) and weather stations (red dots) involved in the data set of the Brown Swiss cow population involved in the present analysis. 
Five DIM classes were defined as follows: from 0 to 30 , from 31 to 90 , from 91 to 180 , from 181 to 270 , and from 271 to 365 . The weather data set was divided into 41 THI maximum classes, with the first class beginning at $\mathrm{THI}=50$ and the subsequent classes were set at each 1-point THI thereafter until the last class, which had a THI $=90$. Parity was grouped into 4 classes: first lactation, second lactation, third lactation, and fourth lactation or more.

In addition to the effects of the weather conditions on the day of milk recording, the effect of the THI for each of the $15 \mathrm{~d}$ before the test-day record was investigated for the outcomes. A range of $15 \mathrm{~d}$ was an arbitrary choice based on the hypothesis that this period is of sufficient length to estimate the duration for which the productive traits are significantly affected by elevated THI.

In the second set of analyses, the least squares means estimated for the levels of the interaction effect between the THI class and the parity class in the model [3] were used as the dependent variable to estimate change points in the relationship between production variables and heat load. These change points would then determine the comfort threshold(s) in these populations. The following model was used:

$$
\mathbf{y}_{i}=\mathbf{x}_{i}^{\mathrm{T}} \boldsymbol{\beta}+\mathbf{u}_{i}(i=1, \ldots, n),
$$

where at time $i, \mathbf{y}_{i}$ is an observation of the dependent variable (e.g., least squared means of production), $\mathbf{x}_{i}{ }^{\mathrm{T}}$ is a $k \times 1$ vector of regressors, with the first component usually equal to unity; $\boldsymbol{\beta}$ is the $k \times 1$ vector of regression coefficients, which may vary over time (THI); and $\mathbf{u}_{i}$ are $\operatorname{iid}\left(0, \sigma^{2}\right)$ (i.e., $\mathbf{u}_{i}$ is a $k \times 1$ vector of residuals, which are independent and identically distributed with mean 0 and standard deviation $\sigma^{2}$ ). In this second phase we tested the null hypothesis that the regression coefficients remain constant (reduced model) compared with the alternative hypothesis that at least 1 coefficient varies over time (complete model). If the increase in the sum of square errors from the complete to the reduced model is significantly large, then the null hypothesis can be rejected, concluding that the complete model works well and a significant breakpoint does exist (i.e., a significant change in milk outcome parameter due to THI has been detected). The analyses were repeated by regressing the least squares means on the THI for each of the $15 \mathrm{~d}$ before the test-day record. The weighted THI was calculated according to the $\mathrm{R}^{2}$ weight of each THI observed.

All tests of statistical significance were 2-tailed, and $P$-values of less than 0.05 were considered significant. The mixed models in the first step of analysis were performed in SAS 9.4 (SAS Institute, Cary NC). The $\mathrm{R}$ software (http://cran.r-project.org) and the "strucchange" package (Zeileis et al., 2002) were used in the second set of analyses. After all analyses, we decided to consider and report the $\mathrm{THI}_{\max }$ effect on all patterns investigated, as this index gave the most consistent results compared with the other ones calculated and considered.

\section{RESULTS}

Descriptive statistics for the Brown Swiss cow population analyzed in the present study are reported in Table 2. Across all parities, MY was not affected by THI independent of the days before test-day record $(P$ $>0.05$; Table 3; Figure 2). Fat-corrected MY were unfavorably affected by increasing THI starting from 15 $\mathrm{d}$ before the test-day in first- and second-parity cows, and 11 and $7 \mathrm{~d}$ before the test-day for third-parity cows and $\geq$ fourth-parity cows, respectively $(P<0.0001)$. The FCM yield loss ranged from a minimum of 0.39 $\mathrm{kg} / \mathrm{d}$ recorded at the same test-day (d 0 ) for cows at second parity $(P<0.01)$ to $1.00 \mathrm{~kg} / \mathrm{d}$ recorded the day before the test-day in cows over the fourth parity $(P$ $<0.0001$ ). The highest and the lowest THI thresholds that affected FCM were observed at $9 \mathrm{~d}$ before the testday in primiparous cows $(\mathrm{THI}=84 ; P<0.01)$ and $6 \mathrm{~d}$ before the test-day in second-parity cows $(\mathrm{THI}=62 ; P$ $<0.01)$, respectively.

In contrast, fat percentage (Table 4) was not affected by the THI $(P>0.05)$. However, fat yield was affected by THI in first-, second-, and third-parity cows, but not in cows from fourth parity onward. The highest and lowest THI values affecting fat yield were both registered in first-parity cows, respectively, at $9(P<$ $0.0001)$ and $5 \mathrm{~d}$ before the test-day $(P<0.01)$. The latter one showed also the lowest slope $(32 \mathrm{~g} / \mathrm{d})$ of fat. The highest negative slope due to THI was also observed in primiparous cows, $14 \mathrm{~d}$ before the test-day $(0.76 \mathrm{~kg} / \mathrm{d} ; P<0.0001)$. Fat yield was negatively affected by THI on more days before the test-day in firstparity cows (10 d of total 16 investigated), compared with second- and third-parity cows (5 and $6 \mathrm{~d}$ of 16 considered before the test-day, respectively). Moreover, the lowest weighted THI breakpoint was observed in third-parity cows (64), whereas first- and second-parity cows had higher weighted THI breakpoints (75 and 77, respectively).

Protein percentage and protein yield (Table 5) were negatively affected by THI increase across all parities, starting from $15 \mathrm{~d}$ before the test-day. The THI breakpoints ranged from 58 ( $15 \mathrm{~d}$ before test-day in $\geq$ fourth-parity cows; $P<0.0001$ ) to 78 (same day of 
Table 2. Description of milk yield $(\mathrm{kg} / \mathrm{d}), \mathrm{FCM}(\mathrm{kg} / \mathrm{d})$, fat and protein percentage, fat and protein yield $(\mathrm{kg} / \mathrm{d})$, cheese yield $(\%)$, ECM ( $\mathrm{kg})$, and cheese production in $24 \mathrm{~h}(\%)$ minimum (min), maximum (max), mean, and SD of the Brown Swiss cow population (subdivided for parity classes) involved in the study

\begin{tabular}{|c|c|c|c|c|c|c|c|c|c|c|}
\hline Parity & Item & $\begin{array}{l}\text { Milk yield, } \\
\mathrm{kg} / \mathrm{d}\end{array}$ & $\begin{array}{l}\mathrm{FCM} \\
\mathrm{kg} / \mathrm{d}\end{array}$ & $\begin{array}{l}\text { Fat, } \\
\%\end{array}$ & $\begin{array}{c}\text { Protein, } \\
\quad \%\end{array}$ & $\begin{array}{l}\text { Fat yield, } \\
\mathrm{kg} / \mathrm{d}\end{array}$ & $\begin{array}{c}\text { Protein } \\
\text { yield, } \mathrm{kg} / \mathrm{d}\end{array}$ & $\begin{array}{l}\text { Cheese } \\
\text { yield, \% }\end{array}$ & $\begin{array}{l}\mathrm{ECM} \\
\mathrm{kg}\end{array}$ & $\begin{array}{c}\text { Cheese production } \\
\text { in } 24 \mathrm{~h}, \%\end{array}$ \\
\hline \multirow[t]{3}{*}{1} & Min & 6.8 & 6.96 & 2.31 & 2.61 & 0.0280 & 0.0233 & 0.02 & 6.99 & 1.10 \\
\hline & Max & 57.5 & 80.94 & 6.15 & 5.09 & 2.7918 & 2.6950 & 0.30 & 64.65 & 5.38 \\
\hline & SD & 6.03 & 6.18 & 0.76 & 0.39 & 0.2759 & 0.2210 & 0.02 & 6.21 & 0.59 \\
\hline \multirow[t]{2}{*}{2} & Min & 6.90 & 7.40 & 2.15 & 1.80 & 0.0334 & 0.0286 & 0.03 & 7.47 & 1.15 \\
\hline & Max & 64.40 & 74.78 & 7.01 & 5.14 & 2.7287 & 2.6002 & 0.28 & 70.61 & 5.03 \\
\hline \multirow[t]{4}{*}{3} & Min & 7.3 & 8.15 & 2.18 & 2.07 & 0.0596 & 0.0475 & 0.03 & 8.24 & 1.33 \\
\hline & Max & 64.9 & 72.77 & 5.67 & 5.87 & 2.4247 & 2.5030 & 0.29 & 76.67 & 4.87 \\
\hline & Mean & 27.650 & 27.75 & 4.05 & 3.66 & 1.1124 & 0.9991 & 0.12 & 28.41 & 2.67 \\
\hline & $\mathrm{SD}$ & 8.6911 & 9.08 & 0.83 & 0.41 & 0.4032 & 0.2956 & 0.02 & 8.93 & 0.86 \\
\hline \multirow{3}{*}{$\geq 4$} & Min & 5.8 & 6.41 & 2.06 & 2.05 & 0.0549 & 0.0960 & 0.03 & 6.69 & 1.18 \\
\hline & Max & 58.5 & 67.48 & 5.14 & 5.98 & 2.4100 & 2.2760 & 0.27 & 63.83 & 4.75 \\
\hline & Mean & 27.51 & 27.44 & 4.00 & 3.60 & 1.0957 & 0.9808 & 0.12 & 28.02 & 2.60 \\
\hline
\end{tabular}

the test-day in third-parity cows; $P<0.0001)$. The lowest THI breakpoint also matched the lowest slope $(-0.11 \% / d)$, whereas the highest slope was $-0.17 \% / d$, recorded $4 \mathrm{~d}$ before the test-day in third-parity cows $(P$ $<0.0001)$. The protein percentage was susceptible to THI on more days in first and in $\geq$ fourth-parity cows ( 7 of $16 \mathrm{~d})$, and the weighted THI breakpoints ranged from 71 in second-parity cows to 74 of the third-parity cows. The highest THI breakpoint for protein yield was observed in first-parity cows $9 \mathrm{~d}$ before the test-day $(84)$, when the lowest slope was recorded $(-17 \mathrm{~g} / \mathrm{d}$; $P<0.01)$. At $7 \mathrm{~d}$ before test-day, primiparous cows showed the lowest THI breakpoint $(-63 ; P<0.0001)$. The highest negative slope was observed in third-parity cows at $6 \mathrm{~d}$ before test-day $(-42 \mathrm{~g} / \mathrm{d} ; P<0.0001)$. The weighted THI breakpoints for protein yield ranged from 75 for first- and second-parity cows to 79 in thirdparity cows. Moreover, first- and second-parity cows showed more days with a significant breakpoint for protein yield (15 and 13, respectively, of 16 considered), whereas the $\geq$ fourth-parity cows had fewer significant days (i.e., only 3 of 16 ).

Cheese yield (\%), ECM (kg) yield, and cheese production in $24 \mathrm{~h}(\%)$ (Table 6) were negatively affected by THI beginning $15 \mathrm{~d}$ before the test-day. Few days showed significant THI breakpoints for cheese yield, but first-parity cows showed the highest number of total days with breakpoints (4 of 16). The THI values ranged from 73 for first-parity cows at $12 \mathrm{~d}$ before test-day $(P$ $<0.0001)$ to 84 for second-parity cows at $10 \mathrm{~d}$ before the test-day $(P<0.0001)$, with slope values ranging from $0.004 \%$ to $0.006 \%(P<0.0001)$. The weighted breakpoints ranged from 74 in primiparous cows to
82 in second-parity cows. The ECM was primarily affected in the few days before test-day (the highest total number of days was 5 of 16 for first-parity cows), although THI could negatively affect ECM as early as $14 \mathrm{~d}$ before test-day. The THI influencing ECM ranged from 55 ( $4 \mathrm{~d}$ before test-day of first-parity cows; $P<$ $0.0001)$ to 84 (10 d before test-day of second-parity cows; $P<0.0001)$. The highest slope was observed $1 \mathrm{~d}$ before the test-day in third-parity cows $(-4.304 \mathrm{~kg} ; P$ $<0.0001$ ), and the minimum slope was recorded $10 \mathrm{~d}$ before test-day of second-parity cows $(-3.248 \mathrm{~kg} ; P<$ 0.0001). Weighted THI breakpoints ranged from 72 for primiparous cows to 79 in second-parity cows. Cheese production in $24 \mathrm{~h}$ was negatively affected by THI, particularly in first- and second-parity cows (in 14 and 12 d before test-day of the 16 investigated, respectively), starting from $15 \mathrm{~d}$ before the test-day. The THI breakpoints ranged from $62(P<0.0001)$ to $84(P<0.01)$, 7 and $9 \mathrm{~d}$ before test-day, respectively, in first-parity cows. The slope ranged from $-0.02 \%(P<0.05)$ at 3 $\mathrm{d}$ before test-day in second lactation cows, to $-0.089 \%$ $(P<0.0001)$ at $7 \mathrm{~d}$ before test-day in $\geq 4$ parity cows. The weighted THI breakpoints ranged from 75 in firstand second-parity cows to 80 in $\geq 4$ parity cows.

\section{DISCUSSION}

Temperature-humidity index has been commonly used to characterize heat stress conditions in dairy cows. It has been shown to give an accurate assessment of animal exposure when they are confined in barns, where the air movement is relatively low and there is no solar radiation (Li et al., 2009), and it can also be easily 


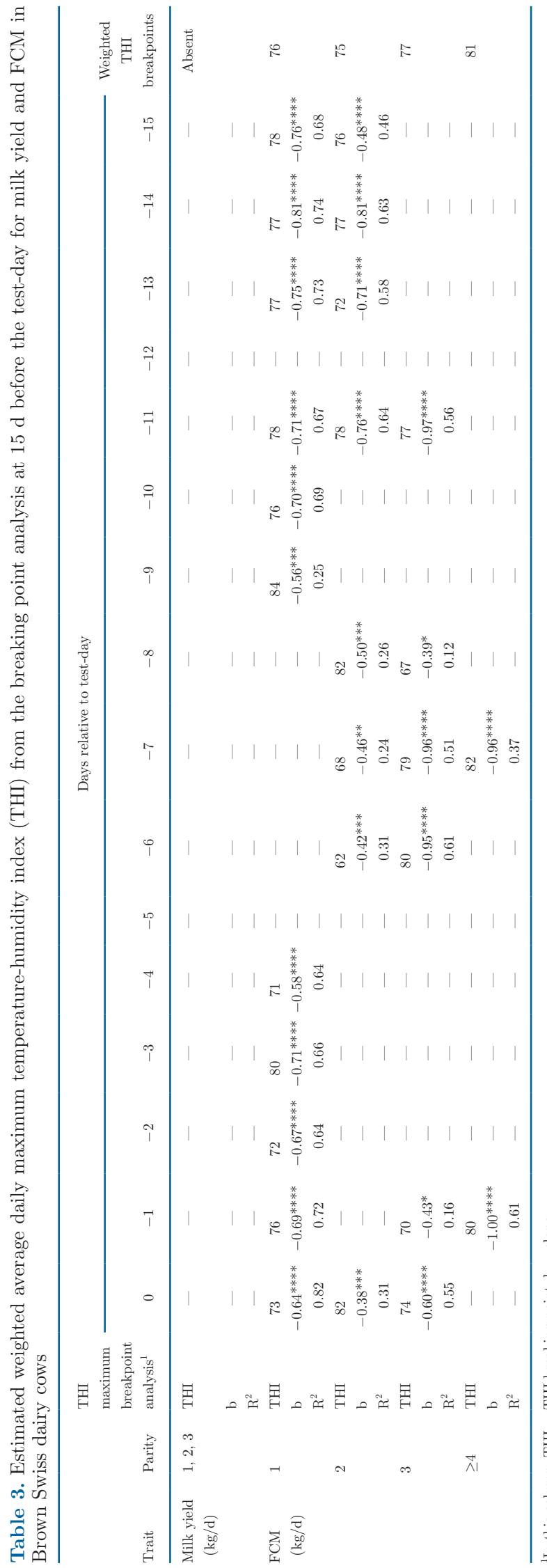

calculated because only air temperature and relative humidity are needed to determine it (Ouellet et al., 2019).

In Holstein cows, several similar studies related to heat stress and MY were conducted globally using weather station data from different climatic areas (Bohmanova et al., 2007; Sánchez et al., 2009; Aguilar et al., 2010; Bernabucci et al., 2014), and THI of 72 was extensively identified and continuously applied as a reference for the heat stress threshold in Holstein dairy cows for MY. Although studies that used the definition of THI of 72 as the reference limit for heat stress were conducted principally in Holstein dairy cows, it has also been used in studies about thermal tolerance in Brown Swiss cows, in comparison to Holstein cows. El-Tarabany et al. (2017), according to this THI limit, studied THI effect on health and MY of different cow breeds and crossbreeds, also comparing Holstein and Brown Swiss cows. El-Tarabany et al. (2017) affirmed that genetic selection for high MY reduces the thermoregulatory ability in dairy animals subjected to heat stress, reporting that Brown Swiss reproductive activity and health were less affected by thermal stress (i.e., lower open days, reduced calving interval, lower incidence of metritis).

In this study, we reported the effects of daily THI maximum because this parameter showed the best fit on the production traits investigated, confirming what it was already known in Holstein cows (Bohlouli et al., 2013; Hammami et al., 2013; Bernabucci et al., 2014; Lambertz et al., 2014; Ouellet et al., 2019).

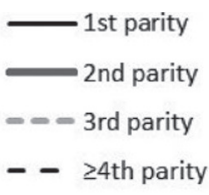

Milk yield

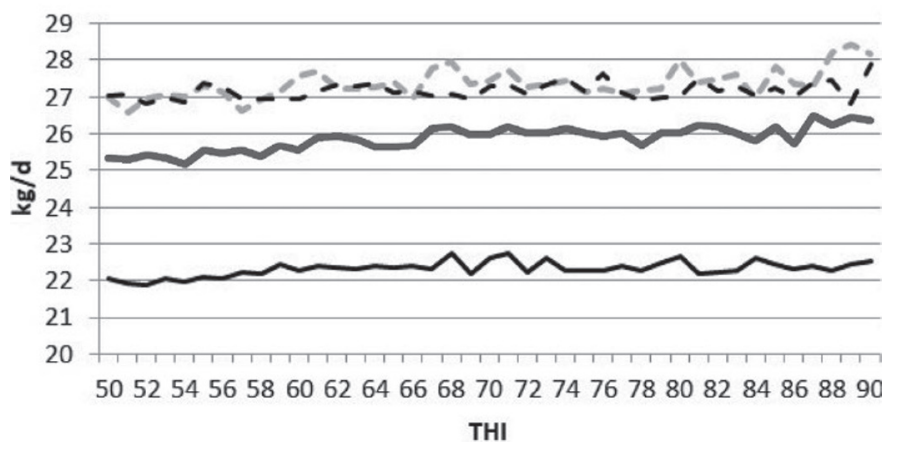

Figure 2. Average milk yield at different temperature-humidity index (THI) calculated on the same day of the milk test-day (d 0) in Brown Swiss cows at first, second, third, and $\geq$ fourth parity. 


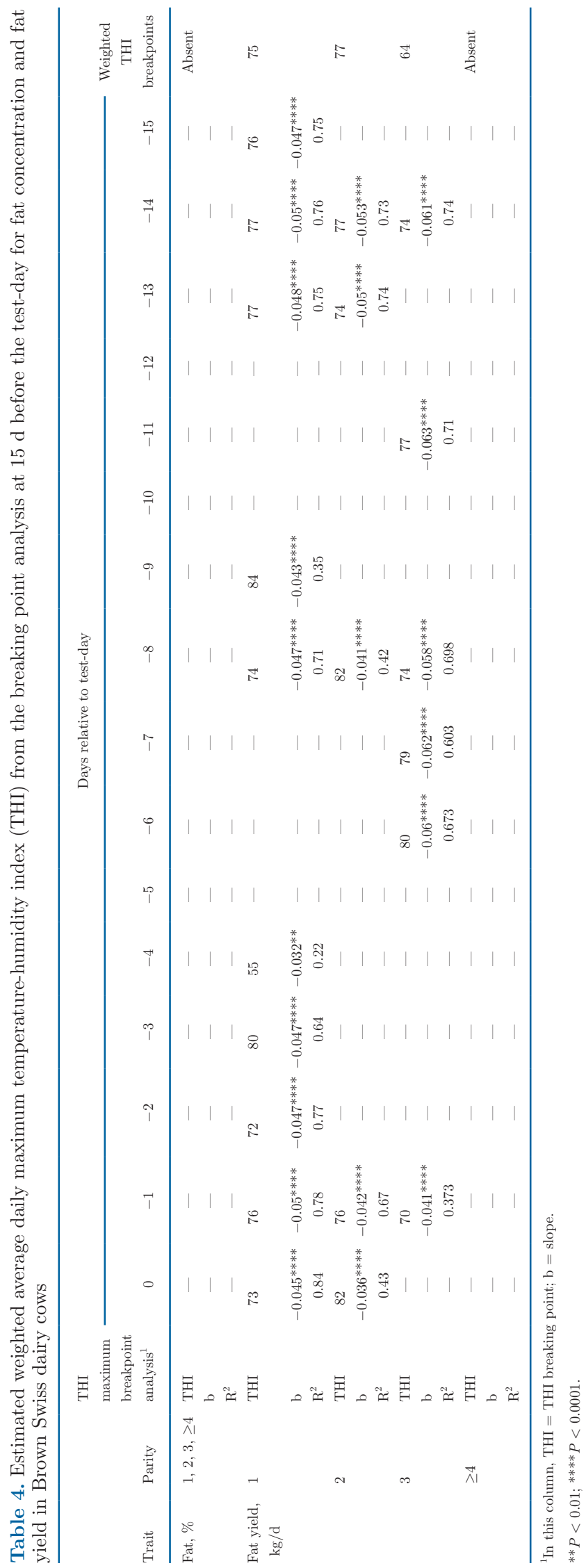

The first important result that is in contrast to work with Holstein cows is the lack of THI breakpoints for MY in Brown Swiss cows, across all parities. Fat-corrected MY, in contrast, showed a better fitting trend with the 2-phase regression model compared with MY in our study. The MY result disagrees with all of the Holstein studies, which have observed significant breakpoints for MY responses to THI (Bernabucci et al., 2014; Amamou et al., 2019). The 2-phase regression approach applied in the present study to test-day MY data of Brown Swiss cows did not identify a THI threshold. In fact, as the THI increased, the MY trend did not change, as it did not show a change in angular coefficient in a specific THI with 2 consequent linear trends. This hypothesis is confirmed by our results; in fact, it is quite clear that MY values tend to show a single linear trend, independent from the THI value. Many authors have reported that heat stress negatively affects MY (Collier et al., 1981; West, 2003; Spiers et al., 2004; Bernabucci et al., 2014; Amamou et al., 2019). However, each form of normalization of MY that incorporated components (FCM, ECM, cheese production estimation) gave us results fitting the 2-phase regression model, highlighting that similar to Holsteins, Brown Swiss results also show a slope of productivity as THI increases, although it does not directly affect MY, but mainly milk constituents (fat and proteins). In fact, FCM showed high THI thresholds, from the weighted THI of 75 of the second-parity cows to the weighted THI of 81 observed in fourth-parity cows. Although the possibility of comparisons with the literature for results obtained for FCM yield is limited, the thresholds observed for Brown Swiss FCM are higher than those reported for MY in Holstein cows (Ravagnolo and Misztal, 2002; Bohmanova et al., 2007; Bryant et al., 2007; Dikmen and Hansen, 2009; Brügemann et al., 2012; Bernabucci et al., 2014). However, FCM yield showed a drop ranging from 0.38 to $1.00 \mathrm{~kg} / \mathrm{d}$ per increase in one THI unit for each Brown Swiss cow. Similar values, although for MY and at lower THI thresholds, were reported in Holstein cows by other authors in Mediterranean basin lands $(0.41 \mathrm{~kg} / \mathrm{d}$ just over THI of 69 , Bouraoui et al., 2002; $0.43 \mathrm{~kg}$ to $1.27 \mathrm{~kg} / \mathrm{d}$ just over a THI of 70, Bernabucci et al., 2014; $0.13 \mathrm{~kg} / \mathrm{d}$ just over THI of 55, Amamou et al., 2019). This different trend of MY between Brown Swiss and Holstein cattle could be linked to a different metabolic response of the animals and mammary gland to heat stress. Negative energy balance in Holsteins tends to affect glucose metabolism and lactose synthesis with a consequent reduction in fluid milk production (Baumgard and Rhoads, 2013). In contrast, Brown Swiss cows may accommodate to heat stress via altered rate of fat and protein metabolism to spare glucose for lactose synthesis. Indeed, 
Maggiolino et al.: HEAT STRESS IN ITALIAN BROWN SWISS

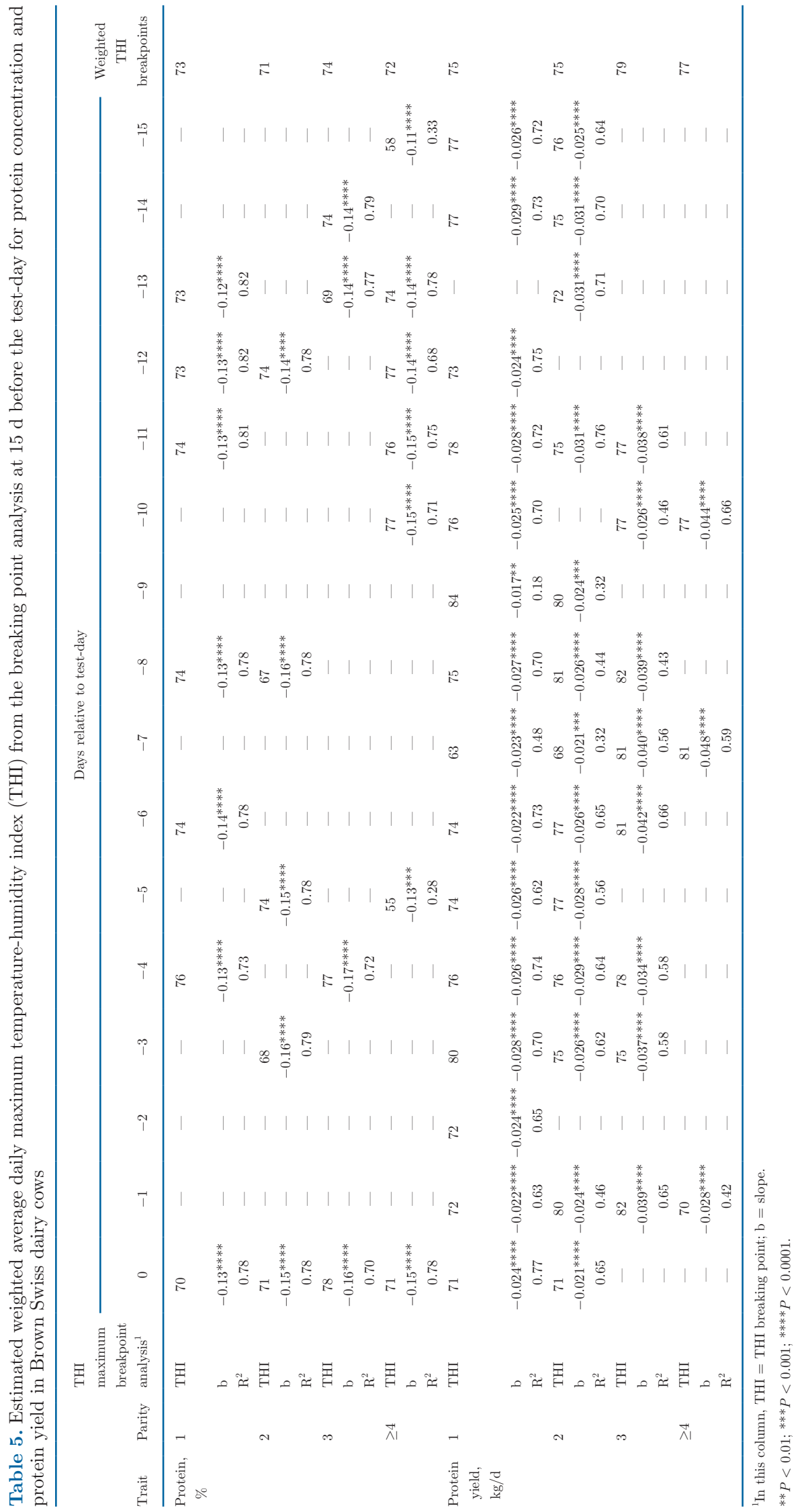


Maggiolino et al.: HEAT STRESS IN ITALIAN BROWN SWISS

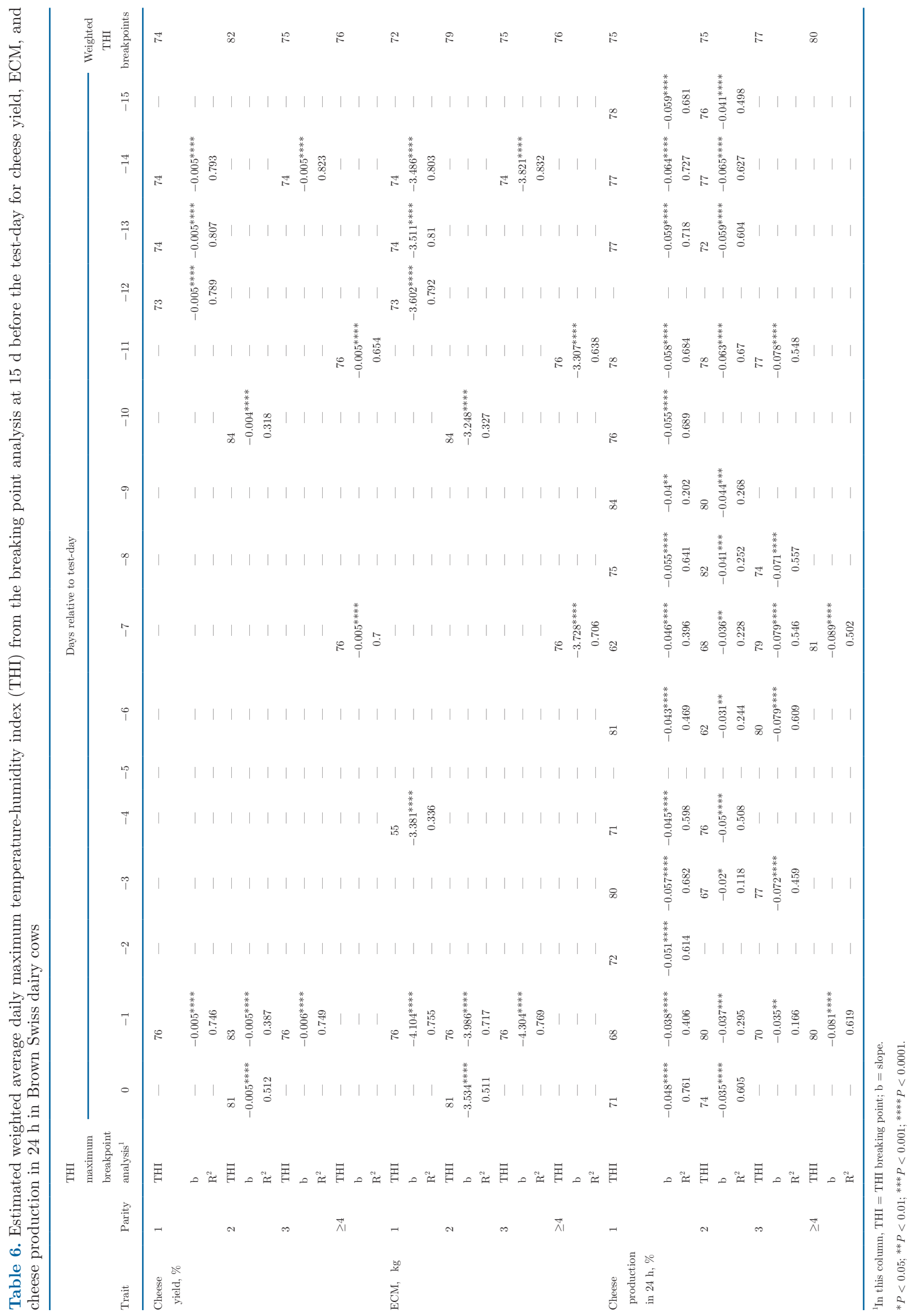


Ouellet et al. (2019), in Holstein cows, observed how weak the link was between exposure to heat stress and milk and lactose yields and concentration, and reported that lactose yield was not associated with heat stress. This hypothesis could explain the different trend of MY in both these breeds at high THI values.

Alternatively, Brown Swiss are overall less productive than Holstein cows (mean lactation production of 75,000 versus 10,000 kg; ANAFI, 2019; ANARB, 2019), and it is well known that the MY levels negatively affect thermal tolerance (Ravagnolo and Misztal, 2002; Wheelock et al., 2010; Bernabucci et al., 2014). So, consistent with the metabolic hypothesis, a lower production level of the overall Italian Brown Swiss population could explain the lack of effect of THI on MY. This does not exclude, however, that within the population, the higher MY animals could be affected by THI in the same way of Holsteins, even if in a general population study this effect is diluted and thus not evident.

The THI breakpoints for fat percentage were not detected for Brown Swiss cows, similar to what was reported by Bernabucci et al. (2014) in Holstein cows. Instead, the other productive traits (fat yield, protein percentage, and protein yield) were affected by THI, with strong evidence of THI thresholds. Fat and protein yields showed a decline ranging from 32 to 53 and from 17 to $42 \mathrm{~g} / \mathrm{cow} / \mathrm{d}$, respectively, for each THI increment above the breakpoint. Decreases in components were comparable to those reported in Holstein cows by Bernabucci et al. (2014) and Ouellet et al. (2019), although at different THI breakpoints. In fact, the thresholds obtained in the present study for Brown Swiss cows are not consistent with what is reported in Holstein cows. We observed a weighted THI of 75 and 77 for fat yield, respectively, at first and second parity in Brown Swiss, compared with 72 and 71 for first and second plus third-parity Holstein cows, respectively, as observed by Bernabucci et al. (2014). Moreover, the weighted THI observed for protein percentage and yield, in all parities considered, ranged from a minimum of 71 to a maximum of 79 , compared with Bernabucci et al. (2014) from 65 to 73 observed in Holsteins. Further, Ouellet et al. (2019) observed that over THI 65, milk constituents and yield of Holstein cows tended to decrease. Ravagnolo et al. (2000) and Bohmanova et al. (2007) defined a THI threshold of 72 above which milk, fat, and protein yields start to decrease, and that is the commonly accepted threshold for the beginning of heat stress (Heinicke et al., 2019). Bouraoui et al. (2002) identified a THI of 69 as the breakpoint beyond which MY starts to decrease. Bryant et al. (2007) reported that THI of 50 and 60 were the breakpoints for fat and protein yields, respectively. Bernabucci et al. (2014) reported THI thresholds rang- ing from 71 to 73 for fat and protein yields and from 73 to 76 for MY. Considering the data for Holstein cows, it seems difficult to reconcile the results obtained in Brown Swiss cows. However, it is clear that THI thresholds for other variables confirm that the Brown Swiss breed has greater thermal tolerance than Holsteins, specifically those related to milk production (Johnson and Vanjonack, 1976; Correa-Calderon et al., 2004), reproductive performance (El-Tarabany and El-Bayoumi, 2015; El-Tarabany and El-Tarabany, 2015; El-Tarabany and Nasr, 2015), physiological traits (Correa-Calderon et al., 2004), behavioral patterns (Dikmen, 2013), and in vitro blood cellular reaction (Lacetera et al., 2006). Thus, the greater heat tolerance of Brown Swiss cows likely extends to their capacity to deal with heat stress with regard to milk production.

According to some authors, the physiological responses of cows to high temperature can be considered as a short-term adaptive process of acclimatization (Kadzere et al., 2002; Bernabucci et al., 2010), and the identification of animals with greater heat tolerance may be useful to maintain high productivity and survivability under heat stress conditions (Gaughan et al., 2009; Bernabucci et al., 2014). However, we still lack adequate knowledge about hyperthermic mechanisms that negatively affect milk synthesis, considering that environmental conditions affect the whole animal in multifactorial ways and not just a single system (Wheelock et al., 2010; Amamou et al., 2019). It is well known that with the increase of THI in Holstein cows there is an increase in physiological variables such as respiration rate and rectal temperature and a reduction in milk, fat, and protein yield (Amamou et al., 2019).

In general, the reduction of feed intake due to heat stress has been considered the main cause for the decreased MY and constituent synthesis (Beede and Collier, 1986; West, 1997). Recent research, however, showed that the reduced nutrient intake of heatstressed cows can account for only approximately $35 \%$ of the reduction of milk synthesis (Rhoads et al., 2009; Wheelock et al., 2010). Indeed, heat stress reduces milk synthesis by both direct and indirect mechanisms (Fan et al., 2019).

Previous studies in Holstein cows indicated that primiparous cows were less sensitive to heat stress than multiparous cows for MY, but more sensitive for milk protein effects (Bernabucci et al., 2014). Those authors speculated that the primiparous resistance to heat stress for MY is due to lower metabolic heat generation and having a greater surface area compared with BW with concomitant efficiency of heat dissipation. Moreover, they produce less milk, which should enhance the ability to cope with heat stress compared with mature cows (Armstrong, 1994; West, 2003; Aguilar et al., 2010). 
In primiparous Brown Swiss cows, we observe a similar greater sensitivity to heat stress for protein yield, and consequently for cheese production, but different results for the other variables. Multiparous cows (over the third parity) had higher average THI thresholds for FCM than cows with 3 or fewer calvings. In contrast, for fat yield the third-parity cows were more sensitive to heat stress, although over the fourth parity there were no THI thresholds.

The negative effects of heat stress on milk constituents (fat and protein) are of particular interest with regard to ECM, cheese yield, and cheese production in $24 \mathrm{~h}$. We opted to evaluate these variables to better understand how heat stress can influence Brown Swiss productivity, from the perspective of manufacturing quality. Cheese yield, representing the weight of cheese obtained from $100 \mathrm{~kg}$ of milk, and the total cheese yield in $24 \mathrm{~h}$, which is used for Parmigiano-Reggiano cheese production, was affected by THI, with weighted breakpoints over THI of 74 . The prediction of cheese yield and ECM represent useful tools for monitoring the efficiency of the cheese-making processes and for monitoring dairy performance (Formaggioni et al., 2015). Weighted THI breakpoints for cheese yield and protein yield are similar, denoting the obvious correlation between these 2 variables. In fact, Bernabucci et al. $(2002,2015)$ reported that casein fractions are particularly affected by heat stress, and they tend to decrease, which affects cheese yield.

\section{CONCLUSIONS}

The present study aims to reveal the effect of maximum daily THI in production of Brown Swiss dairy cows. Results indicate that heat stress negatively affects cow performance, although heat stress effects in Brown Swiss occur at a higher THI than that reported for Holstein cows, about 2 to 3 points more than Holstein cows for most of the variables investigated. The primary result of interest is that absolute MY, in contrast to other variables, is not affected by heat stress. This suggests a slightly different metabolic response of Brown Swiss cows relative to Holstein cows, probably related to the different production level between these 2 breeds. However, the decline of milk quality in Brown Swiss with heat exposure presents the same trends as in Holsteins, even if at higher THI thresholds. Because Brown Swiss are usually selected for cheese production and milk quality in this breed tends to decline at THI similar to the Holstein, heat stress represents an important issue that is usually underestimated. Therefore, actions aimed at reducing heat stress effects on Brown Swiss, both from a genetic perspective and from a management point of view, are necessary for avoiding economic losses that might be overlooked when only considering milk output. However, further studies will be necessary to estimate the genetic merit and production level of MY on THI thresholds, and to estimate genetic components of heat tolerance, considering that estimation of THI thresholds represents the first step in the use of such information in selection programs to mitigate heat stress in dairy cattle.

\section{ACKNOWLEDGMENTS}

The present paper has been edited during the visiting period of Geoffry E. Dahl to the Department of Veterinary Medicine of Bari, granted by the University of Bari Aldo Moro (D.R. n. 1574 del 13.03.2019). The authors are grateful to Vincenzo Landi (Department of Veterinary Medicine, University of Bari Aldo Moro), Giovanna Calzaretti (Department of Veterinary Medicine, University of Bari Aldo Moro), and Mayra Gomez Carpio (Italian Buffalo Breeders Association, Caserta, Italy) for their technical support. Moreover, the authors are grateful to Marco Giazzi and Marco Tadini, the president and vice president, respectively, of the Meteonetwork association (www.meteonetwork.it) and to Italian Air Force weather service (www.aeronautica .difesa.it) for giving us access to all weather station data. The authors declare no conflict of interest.

\section{REFERENCES}

Aguilar, I., I. Misztal, and S. Tsuruta. 2010. Genetic trends of milk yield under heat stress for US Holsteins. J. Dairy Sci. 93:17541758. https://doi.org/10.3168/jds.2009-2756.

Allen, J. D., L. W. Hall, R. J. Collier, and J. F. Smith. 2015. Effect of core body temperature, time of day, and climate conditions on behavioral patterns of lactating dairy cows experiencing mild to moderate heat stress. J. Dairy Sci. 98:118-127. https://doi.org/10 $.3168 /$ jds.2013-7704.

Amamou, H., Y. Beckers, M. Mahouachi, and H. Hammami. 2019. Thermotolerance indicators related to production and physiological responses to heat stress of Holstein cows. J. Therm. Biol. 82:90-98. https://doi.org/10.1016/j.jtherbio.2019.03.016.

Armstrong, D. V. 1994. Heat stress interaction with shade and cooling. J. Dairy Sci. 77:2044-2050. https://doi.org/10.3168/jds.S0022 -0302(94)77149-6.

Associazione Nazionale della Razza Bruna Italiana (ANARB). 2019. La Razza Bruna. Accessed Feb. 10, 2020. http://www.anarb.it/chi -siamo/la-razza-bruna/.

Associazione Nazionale della razza Frisona Italiana (ANAFI). 2019. Statistiche Nazionali: Medie Produzioni Latte/Grasso/Proteine Vacche Razza Frisona Controllate. Accessed Feb. 10, 2020. http: //www.anafi.it/it/pubblicazioni-statistiche/statistiche-nazionali -2019 .

Baumgard, L. H., and R. P. Rhoads Jr.. 2013. Effects of heat stress on postabsorptive metabolism and energetics. Annu. Rev. Anim. Biosci. 1:311-337. https://doi.org/10.1146/annurev-animal-031412 -103644 .

Beede, D. K., and R. J. Collier. 1986. Potential nutritional strategies for intensively managed cattle during thermal stress. J. Anim. Sci. 62:543-554. https://doi.org/10.2527/jas1986.622543x.

Bernabucci, U., L. Basiricò, P. Morera, D. Dipasquale, A. Vitali, F. Piccioli Cappelli, and L. Calamari. 2015. Effect of summer season 
on milk protein fractions in Holstein cows. J. Dairy Sci. 98:18151827. https://doi.org/10.3168/jds.2014-8788.

Bernabucci, U., S. Biffani, L. Buggiotti, A. Vitali, N. Lacetera, and A. Nardone. 2014. The effects of heat stress in Italian Holstein dairy cattle. J. Dairy Sci. 97:471-486. https://doi.org/10.3168/jds.2013 $-6611$.

Bernabucci, U., N. Lacetera, L. H. Baumgard, R. P. Rhoads, B. Ronchi, and A. Nardone. 2010. Metabolic and hormonal acclimation to heat stress in domesticated ruminants. Animal 4:1167-1183. https: //doi.org/10.1017/S175173111000090X.

Bernabucci, U., N. Lacetera, B. Ronchi, and A. Nardone. 2002. Effects of the hot season on milk protein fractions in Holstein cows. Anim. Res. 51:25-33. https://doi.org/10.1051/animres:2002006.

Beux, S., M. Cassandro, A. Nogueira, and N. Waszczynskyj. 2017. Effect of THI on milk coagulation properties of Holstein-Friesian dairy cattle. Rev. Bras. Zootec. 46:429-432. https://doi.org/10 .1590/s1806-92902017000500009.

Bohlouli, M., J. Shodja, S. Alijani, and A. Eghbal. 2013. The relationship between temperature-humidity index and test-day milk yield of Iranian Holstein dairy cattle using random regression model. Livest. Sci. 157:414-420. https://doi.org/10.1016/j.livsci.2013.09 .005 .

Bohmanova, J., I. Misztal, and J. B. Cole. 2007. Temperature-humidity indices as indicators of milk production losses due to heat stress. J. Dairy Sci. 90:1947-1956. https://doi.org/10.3168/jds.2006-513.

Bouraoui, R., M. Lahmar, A. Majdoub, M. Djemali, and R. Belyea. 2002. The relationship of temperature-humidity index with milk production of dairy cows in a Mediterranean climate. Anim. Res. 51:479-491. https://doi.org/10.1051/animres:2002036.

Brügemann, K., E. Gernand, U. König von Borstel, and S. König. 2012. Defining and evaluating heat stress thresholds in different dairy cow production systems. Arch. Tierzucht 55:13-24. https:// doi.org/10.5194/aab-55-13-2012.

Bryant, J. R., N. Lopez-Villalobos, J. E. Pryce, C. W. Holmes, D. L. Johnson, and D. J. Garrick. 2007. Environmental sensitivity in New Zealand dairy cattle. J. Dairy Sci. 90:1538-1547. https://doi .org/10.3168/jds.S0022-0302(07)71639-9.

Cassandro, M. 2020. Animal breeding and climate change, mitigation and adaptation. J. Anim. Breed. Genet. 137:121-122. https://doi .org/10.1111/jbg. 12469 .

Cincović, M., B. Belić, B. Toholj, and M. Stevančević. 2011. On-farm measurement of heat stress load in dairy cows. Vet. Stn. 42:285289.

Collier, R. J., R. M. Eley, A. K. Sharma, R. M. Pereira, and D. E. Buffington. 1981. Shade management in subtropical environment for milk yield and composition in Holstein and Jersey cows. J. Dairy Sci. 64:844-849. https://doi.org/10.3168/jds.S0022-0302(81)82656 -2 .

Correa-Calderon, A., D. Armstrong, D. Ray, S. DeNise, M. Enns, and C. Howison. 2004. Thermoregulatory responses of Holstein and Brown Swiss heat-stressed dairy cows to two different cooling systems. Int. J. Biometeorol. 48:142-148. https://doi.org/10.1007/ s00484-003-0194-y.

De Palo, P., A. Tateo, F. Zezza, M. Corrente, and P. Centoducati. 2006. Influence of free-stall flooring on comfort and hygiene of dairy cows during warm climatic conditions. J. Dairy Sci. 89:45834595. https://doi.org/10.3168/jds.S0022-0302(06)72508-5.

Dikmen, S. 2013. The effect of breed in a hot environment on some welfare indicators in feedlot cattle. Span. J. Agric. Res. 11:1028 1035. https://doi.org/10.5424/sjar/2013114-3834.

Dikmen, S., and P. J. Hansen. 2009. Is the temperature-humidity index the best indicator of heat stress in lactating dairy cows in a subtropical environment? J. Dairy Sci. 92:109-116. https://doi .org/10.3168/jds.2008-1370.

El-Tarabany, M. S., and K. M. El-Bayoumi. 2015. Reproductive performance of backcross Holstein $\times$ Brown Swiss and their Holstein contemporaries under subtropical environmental conditions. Theriogenology 83:444-448. https://doi.org/10.1016/j.theriogenology .2014.10.010

El-Tarabany, M. S., and A. A. El-Tarabany. 2015. Impact of maternal heat stress at insemination on the subsequent reproductive perfor- mance of Holstein, Brown Swiss, and their crosses. Theriogenology 84:1523-1529. https://doi.org/10.1016/j.theriogenology.2015 .07 .040 .

El-Tarabany, M. S., and M. A. Nasr. 2015. Reproductive performance of Brown Swiss, Holstein and their crosses under subtropical environmental conditions. Theriogenology 84:559-565. https://doi .org/10.1016/j.theriogenology.2015.04.012.

El-Tarabany, M. S., E. M. Roushdy, and A. A. El-Tarabany. 2017. Production and health performance of Holstein, Brown Swiss and their crosses under subtropical environmental conditions. Anim. Prod. Sci. 57:1137-1143. https://doi.org/10.1071/AN15809.

Endres, M. I., and A. E. Barberg. 2007. Behavior of dairy cows in an alternative bedded-pack housing system. J. Dairy Sci. 90:41924200. https://doi.org/10.3168/jds.2006-751.

Fan, C., D. Su, H. Tian, R. Hu, L. Ran, Y. Yang, Y. Su, and J. Cheng. 2019. Milk production and composition and metabolic alterations in the mammary gland of heat-stressed lactating dairy cows. J. Integr. Agric. 18:2844-2853. https://doi.org/10.1016/ S2095-3119(19)62834-0.

Formaggioni, P., A. Summer, M. Malacarne, P. Franceschi, and G. Mucchetti. 2015. Italian and Italian-style hard cooked cheeses: Predictive formulas for Parmigiano-Reggiano 24-h cheese yield. Int. Dairy J. 51:52-58. https://doi.org/10.1016/j.idairyj.2015.07 .008 .

Gaines, W. L., and F. A. Davidson. 1923. Relationship between percentage fat content and yield of milk. Illinois Agricultural Experimentation Station Bulletin. University of Illinois, Urbana-Champaign.

Gaughan, J., N. Lacetera, S. E. Valtorta, H. H. Khalifa, L. Hahn, and T. Mader. 2009. Response of domestic animals to climate challenges. Pages 131-170 in Biometeorology for Adaptation to Climate Variability and Change. Springer, Dordrecht, the Netherlands.

Hammami, H., J. Bormann, N. M'hamdi, H. H. Montaldo, and N. Gengler. 2013. Evaluation of heat stress effects on production traits and somatic cell score of Holsteins in a temperate environment. J. Dairy Sci. 96:1844-1855. https://doi.org/10.3168/jds.2012-5947.

Heinicke, J., G. Hoffmann, C. Ammon, B. Amon, and T. Amon. 2018. Effects of the daily heat load duration exceeding determined heat load thresholds on activity traits of lactating dairy cows. J. Therm. Biol. 77:67-74. https://doi.org/10.1016/j.jtherbio.2018.08.012.

Heinicke, J., S. Ibscher, V. Belik, and T. Amon. 2019. Cow individual activity response to the accumulation of heat load duration. J. Therm. Biol. 82:23-32. https://doi.org/10.1016/j.jtherbio.2019.03 .011 .

Herbut, P., and S. Angrecka. 2018. Relationship between THI level and dairy cows' behaviour during summer period. Ital. J. Anim. Sci. 17:226-233. https://doi.org/10.1080/1828051X.2017.1333892.

Hill, D. L., and E. Wall. 2015. Dairy cattle in a temperate climate: The effects of weather on milk yield and composition depend on management. Animal 9:138-149. https://doi.org/10.1017/ S1751731114002456.

ICAR. 2019. The International Committee for Animal Recording. https://www.icar.org/index.php/icar-recording-guidelines/

Jeelani, R., D. Konwar, A. Khan, D. Kumar, D. Chakraborty, and B. Brahma. 2019. Reassessment of temperature-humidity index for measuring heat stress in crossbred dairy cattle of a sub-tropical region. J. Therm. Biol. 82:99-106. https://doi.org/10.1016/j .jtherbio.2019.03.017.

Johnson, H. D., and W. J. Vanjonack. 1976. Effects of environmental and other stressors on blood hormone patterns in lactating animals. J. Dairy Sci. 59:1603-1617. https://doi.org/10.3168/jds .S0022-0302(76)84413-X.

Kadzere, C. T., M. R. Murphy, N. Silanikove, and E. Maltz. 2002. Heat stress in lactating dairy cows: A review. Livest. Prod. Sci. 77:59-91. https://doi.org/10.1016/S0301-6226(01)00330-X.

Lacetera, N., U. Bernabucci, D. Scalia, L. Basiricò, P. Morera, and A. Nardone. 2006. Heat stress elicits different responses in peripheral blood mononuclear cells from Brown Swiss and Holstein cows. J. Dairy Sci. 89:4606-4612. https://doi.org/10.3168/jds.S0022 $-0302(06) 72510-3$ 
Lambertz, C., C. Sanker, and M. Gauly. 2014. Climatic effects on milk production traits and somatic cell score in lactating Holstein-Friesian cows in different housing systems. J. Dairy Sci. 97:319-329. https://doi.org/10.3168/jds.2013-7217.

Li, S., K. G. Gebremedhin, C. N. Lee, and R. J. Collier. 2009. Evaluation of thermal stress indices for cattle. Page 1 in 2009 Reno, Nevada. American Society of Agricultural and Biological Engineers, St. Joseph, MI.

Nardone, A., B. Ronchi, N. Lacetera, M. S. Ranieri, and U. Bernabucci. 2010. Effects of climate changes on animal production and sustainability of livestock systems. Livest. Sci. 130:57-69. https:// doi.org/10.1016/j.livsci.2010.02.011.

Nasr, M. A., and M. S. El-Tarabany. 2017. Impact of three THI levels on somatic cell count, milk yield and composition of multiparous Holstein cows in a subtropical region. J. Therm. Biol. 64:73-77. https://doi.org/10.1016/j.jtherbio.2017.01.004.

Ouellet, V., V. E. Cabrera, L. Fadul-Pacheco, and E. Charbonneau. 2019. The relationship between the number of consecutive days with heat stress and milk production of Holstein dairy cows raised in a humid continental climate. J. Dairy Sci. 102:8537-8545. https: //doi.org/10.3168/jds.2018-16060.

Ravagnolo, O., and I. Misztal. 2002. Studies on genetics of heat tolerance in dairy cattle with reduced weather information via cluster analysis. J. Dairy Sci. 85:1586-1589. https://doi.org/10.3168/jds .S0022-0302(02)74228-8.

Ravagnolo, O., I. Misztal, and G. Hoogenboom. 2000. Genetic component of heat stress in dairy cattle, development of heat index function. J. Dairy Sci. 83:2120-2125. https://doi.org/10.3168/jds S0022-0302(00)75094-6.

Rhoads, M. L., R. P. Rhoads, M. J. VanBaale, R. J. Collier, S. R. Sanders, W. J. Weber, B. A. Crooker, and L. H. Baumgard. 2009. Effects of heat stress and plane of nutrition on lactating Holstein cows: I. Production, metabolism, and aspects of circulating somatotropin. J. Dairy Sci. 92:1986-1997. https://doi.org/10.3168/ jds.2008-1641.

Sánchez, J. P., I. Misztal, I. Aguilar, B. Zumbach, and R. Rekaya. 2009. Genetic determination of the onset of heat stress on daily milk production in the US Holstein cattle. J. Dairy Sci. 92:40354045. https://doi.org/10.3168/jds.2008-1626.

Spiers, D. E., J. N. Spain, J. D. Sampson, and R. P. Rhoads. 2004. Use of physiological parameters to predict milk yield and feed intake in heat-stressed dairy cows. J. Therm. Biol. 29:759-764. https://doi .org/10.1016/j.jtherbio.2004.08.051.
Uzal Seyfi, S. 2013. Seasonal variation of the lying and standing behavior indexes of dairy cattle at different daily time periods in free-stall housing. Anim. Sci. J. 84:708-717. https://doi.org/10 $.1111 /$ asj.12062.

Van Slyke, L. L., and C. A. Publow. 1910. The Science and Practice of Cheese-Making. Orange Judd Co., New York, NY.

West, J. W. 1997. Nutritional strategies for managing the heatstressed dairy cow. J. Anim. Sci. 77(suppl_2):21-35. https://doi .org/10.2527/1997.77suppl_221x.

West, J. W. 2003. Effects of heat-stress on production in dairy cattle. J. Dairy Sci. 86:2131-2144. https://doi.org/10.3168/jds.S0022 -0302(03)73803-X.

Wheelock, J. B., R. P. Rhoads, M. J. VanBaale, S. R. Sanders, and L. H. Baumgard. 2010. Effects of heat stress on energetic metabolism in lactating Holstein cows. J. Dairy Sci. 93:644-655. https://doi .org/10.3168/jds.2009-2295.

WMO. 2019. World Meteorological Organization. Standards and recommended practices. https://public.wmo.int/en/resources/ standards-technical-regulations.

Zeileis, A., F. Leisch, K. Hornik, and C. Kleiber. 2002. Strucchange: An $\mathrm{R}$ package for testing for structural change. J. Stat. Softw. 7:1-38. https://doi.org/10.18637/jss.v007.i02.

Zimbelman, R. B., R. P. Rhoads, M. L. Rhoads, G. C. Duff, L. H. Baumgard, and R. J. Collier. 2009. A re-evaluation of the impact of temperature humidity index (THI) and black globe humidity index (BGHI) on milk production in high producing dairy cows. Pages 158-169 in Proceedings of the Western Dairy Management Conference, Tempe, AZ. University of Arizona, Tucson.

\section{ORCIDS}

A. Maggiolino ( https://orcid.org/0000-0001-7128-8556

G. E. Dahl ๑ https://orcid.org/0000-0002-2182-6317

N. Bartolomeo () https://orcid.org/0000-0002-8540-4615

U. Bernabucci ๑ https://orcid.org/0000-0002-8126-3042

A. Vitali $\odot$ https://orcid.org/0000-0002-4739-9077

G. Serio ๑ https://orcid.org/0000-0001-5329-571X

M. Cassandro (i) https://orcid.org/0000-0002-8709-2870

P. De Palo ๑ https://orcid.org/0000-0002-5612-1691 